IJOTL TL, Vol. 5, No. 1, January 2020

p ISSN: 2502 2326; e ISSN: 2502 8278

Https://soloclcs.org; Email: ijolt1@gmail.com

Center of Language and Cultural Studies, Surakarta, Indonesia

Rustanto, Kristina; Nur, Dedi Rahman \& Mitriana, Rinda. 2020. Exploring the Use of TPACK

in Teaching Listening.

IJOTL TL (2020), 5(1): 45 50. DOI: 10.30957/ijot1 -1.v5i1.614

\title{
Exploring the Use TPACK in Teaching Listening
}

\author{
Kristina Rustanto ${ }^{1}$, Dedi Rahman Nur ${ }^{1} \&$ Rinda Mitriana ${ }^{1}$ \\ University of Widya Gama Mahakam Samarinda \\ Corressponding email: ${ }^{1}$ kristinarustanto8@gmail.com \\ 1dedirahmannur@uwgm.ac.id \\ 1rinda@uwgm.ac.id
}

\begin{abstract}
This research study Exploring of the use TPACK framework in listening classroom. This research focus on how the teacher develop instrument design in listening classroom with TPACK framework. Data collection consisted of classroom observation, check list with indicator guide and field notes Findings the result there is different the teacher 1 and 2 with develop instrument design in listening classroom with TPACK Framework. The different teacher 1 dominant with CK ( content knowledge) and PK ( pedagogical knowledge) and able to is able to design lesson plan involved technology, taught used technology that appropriate with learning material, and she manage the class by using technology. This the conclusion of the research in SMA Budi Bakti about developing instrument design in listening classroom with TPACK framework
\end{abstract}

Keywords: Tpack Framework, Teaching Pratice, and Instructional design

\section{INTRODUCTION}

In this time life in era globalization, there is a lot about modernization include many things one of them the increase use technology. In this era modernization many people rely with technology. As an international phenomenon, technology is an important part of our everyday lives and efforts to improve teaching and learning (Roblyer, 2006). Today, more than ever, the role of educational technology in teaching is of great importance because of the use of information and communication technologies. With the help of various applications for distance education, the Internet, teachers, and students themselves, they see the advantage of educational technology.

According Shulman 1986 Effective teaching built on teachers understand about the material for teaching and student it's mean as a be professional teacher we must be comprehend where the place the teacher teaching that makes know what the framework suitable with the students and students can be understand with the material. Teachers are educated people and model interacting with students in school. Teachers have a work plan and to do the learning process, provide rate, open communication with people, provide training and guidance and important have strategy with the effective method.In this research I will be focus with one of English skill component it is listening major 
IJOTL TL, Vol. 5, No. 1, January 2020

p ISSN: 2502 2326; e ISSN: 2502 8278

Https://soloclcs.org; Email: ijolt1@gmail.com

Center of Language and Cultural Studies, Surakarta, Indonesia

Rustanto, Kristina; Nur, Dedi Rahman \& Mitriana, Rinda. 2020. Exploring the Use of TPACK

in Teaching Listening.

IJOTL TL (2020), 5(1): 45 50. DOI: 10.30957/ijot1 -1.v5i1.614

(Arbain Arbain, Taufik, Ngoc, \& Nur, 2017; Arbain Arbain, Taufik, \& Nur, 2017; A. Arbain, 2017).

Graham (2006) said that there are some other factors that increase learners' listening comprehension problems such as restricted vocabulary, poor grammar, and misinterpretations about listening tasks.

There is some learner said so difficult to learning listening because sometime less understanding about what the teacher said or about the method teacher use in learning listening and then still there some difficult learning listening will be discuss about that on chapter II. Of the difficulties experienced by the learner the does not mean just the learner wrong in learning but as a professional teacher should be able to see what the strategy or method in learning is suitable to my learner. To package the method of learning must have special skills for a teacher. Not just enough (content), or designing learning skill (pedagogical) but must be combine content and pedagogical and then not just use the both but can using technology so this is often called TPACK (Technological Pedagogical and Content Knowledge). Because life in the era of modernization need method in learning with technology. Other than that method is important in education. Method is way the teacher use to connecting with learner in teaching and method is way to achieve learning goal.

Therefore can be interpreted the method in learning process is conceptual framework which describes a systematic procedure in organizing learning experiences to achieve specific learning goals. In this research the learning method is produced leraning process method with TPACK framework which is arranged in designed in learning blended learning so that learner can be follow the online learning systematically the material, media and methods have been systematically packaged so as to facilitate learners. PCK according Shulman, Mishra and Koehler (2006) already increases the technology for PCK and give picture about TPACK be connected between technology, pedagogic, and content. Tpack is basic from a good teaching with technology and require about delegation concept about how to use technology. in this case TPACK make effective to learning specifically learning English listening. Therefore the writing explains about teaching listening by TPACK.

\section{METHODS}

Research is the formal, systematic application of the scientific method to the study of problems and the goal to describe, explain, predict, or control phenomena in this case, educational phenomena (Gay 2012). It means research the development and testing theory. This research is a qualitative research. Qualitative research is the collection and analysis explain comprehensive narrative and data visual (non-numeric to get the knowledge in the research. Qualitative research Characteristics exploratory and understanding-oriented (Creswell, John W 2012). The write choose this method because corresponding with the researcher data. The design Narrative research is describe about the live individual,collect, and tell the stories about people live and write narrative of individual experience (Connelly \& Clandinin, 1990). Narrative Research Use 
Willing to tell \& report someone stories \& the stories follow a chronology of event and type of Narrative designs important for researcher, but for those readers most important to recognize the essential characteristics of the type. Examples of type of Narrative Research: Autobiograhies, Biographies and then The researchers focus on individual experiences. In this research, the focus experience the teacher framework to teaching listening classroom in SMA Budi Bakti Samarinda. In this research will be implemented in 1 Month October ( 3 meetings) and The subjects of the research were the SMA Budi Bakti Samarinda. There is two English teacher in SMA Budi Bakti. The researcher chose that school because based on the observation, the school related with the researcher research and the researcher chooses the subjects by purposive sampling, which it is, one of techniques to choosing the subjects of qualitative research. In term, Creswell (2012) marked that purposeful sampling is the term used for qualitative sampling. Selected the sample is the important step in conducting a research study.

\section{FINDINGS AND DISCUSSION}

This research aimed to find (1) How teacher develop instrument design in listening classroom with TPACK Framework? To collect the data, the researcher conducted an observed the teacher teaching listening and check list with indicator the components TPACK framework.

The teacher develop instrument design in listening classroom with TPACK framework to find out how the teacher develop instrument design in listening classroom with TPACK framework, the researcher observed two teacher teaches in listening classroom by reference Mishra, Koehler \& Bragg (2006) check list what the dominant with indicator the components of TPACK framework.

On this research observation the teacher taught in listening classroom with apply TPACK framework and there is three meeting in this research. From this researched the researcher find the result related with the title and the result from this research focus with guide indicator:

As shown in table 1, from two teacher English in SMA Budi Bakti about develop instrument design TPACK Framework in listening classroom with TPACK Framework: In the first meeting, the first teacher 1 did not develop TK ( Technology knowledge) he used audio for teaching listening and he did not used program, software, internet, multimedia etc.

Second the teacher 1 develop CK (content knowledge) in the teaching listening classroom he taught listening material appropriate with the syllabus and he involved knowledge of general facts, concepts, and theories its mean he explained the material on the start taught.

Third the teacher 1 develop PK (Pedagogical Knowledge) The teacher able applies theory of classroom management in class for the observed he used group strategic in taught listening like he gave the student number and next the student sit with the group and listening audio and answer together next the student discussion. 
IJOTL TL, Vol. 5, No. 1, January 2020

p ISSN: 2502 2326; e ISSN: 2502 8278

Https://soloclcs.org; Email: ijolt1@gmail.com

Center of Language and Cultural Studies, Surakarta, Indonesia

Rustanto, Kristina; Nur, Dedi Rahman \& Mitriana, Rinda. 2020. Exploring the Use of TPACK

in Teaching Listening.

IJOTL TL (2020), 5(1): 45 50. DOI: 10.30957/ijotl tl.v5i1.614.

Furthermore the teacher able to make effective lesson plan and syllabus, made assessment and evaluation learning, and able to communication with the student.

TABLE 1. Knowledge Components in the Listening Classroom Teachers

\begin{tabular}{|c|c|c|c|}
\hline \multirow{2}{*}{$\begin{array}{c}\text { The } \\
\text { components of } \\
\text { TPACK }\end{array}$} & \multirow[t]{2}{*}{ Indicator } & \multicolumn{2}{|c|}{$\begin{array}{c}\text { First Meeting } \\
1 \& 2\end{array}$} \\
\hline & & Teacher 1 & Teacher 2 \\
\hline \multirow[t]{3}{*}{$\mathrm{TK}$} & $\begin{array}{l}\text { 1. The teacher teaches by using } \\
\text { technologies, such as the } \\
\text { internet and digital video }\end{array}$ & & $\sqrt{ }$ \\
\hline & $\begin{array}{l}\text { 2. The teacher teaches using } \\
\text { hardware and software } \\
\text { programs }\end{array}$ & & $\sqrt{ }$ \\
\hline & $\begin{array}{l}\text { 3. The teacher activities involved } \\
\text { media such as animation } \\
\text { movie, short movie, youtube, } \\
\text { podcast,and type of audio }\end{array}$ & $\sqrt{ }$ & $\sqrt{ }$ \\
\hline \multirow[t]{2}{*}{ CK } & $\begin{array}{l}\text { 1. The teacher teaches learning } \\
\text { material appropriate with the } \\
\text { syllabus }\end{array}$ & $\sqrt{1}$ & $\sqrt{ }$ \\
\hline & $\begin{array}{l}\text { 2. The teacher involved } \\
\text { knowledge of general facts, } \\
\text { concepts, and theories }\end{array}$ & & $\sqrt{ }$ \\
\hline \multirow[t]{4}{*}{ PK } & $\begin{array}{l}\text { 1. The teacher applies theory of } \\
\text { classroom management in } \\
\text { class }\end{array}$ & $\sqrt{1}$ & $\sqrt{ }$ \\
\hline & $\begin{array}{l}\text { 2. The teacher is able to make } \\
\text { effective lesson plan and } \\
\text { syllabus }\end{array}$ & $\sqrt{ }$ & $\sqrt{ }$ \\
\hline & $\begin{array}{l}\text { 3. The teacher make assessment } \\
\text { and evaluation learning }\end{array}$ & $\sqrt{ }$ & $\sqrt{ }$ \\
\hline & $\begin{array}{l}\text { 4. The teacher is able to } \\
\text { communication with the } \\
\text { student }\end{array}$ & $\sqrt{ }$ & $\sqrt{ }$ \\
\hline TPACK & $\begin{array}{l}\text { 1. The teachers is able to design } \\
\text { lesson plan involved } \\
\text { technology } \\
\text { 2. The teacher teaches used } \\
\text { technology that appropriate } \\
\text { with learning material } \\
\text { 3. The teacher can manage the } \\
\text { class by using technology }\end{array}$ & & $\sqrt{ }$ \\
\hline
\end{tabular}

Fourth the teacher 1 did not develop TPACK in listening classroom. He did not able to design lesson plan involved technology, did not teaches used technology that 
appropriate with learning material the teacher just only used audio in taught listening, and he did not manage the class by using technology.

Meanwhile in the first meeting the first teacher 2 develop (TK) Technology knowledge she able to used technology such as digital and internet, used program and software in taught listening the program from Cambridge book, and able to used media for example she used audio with taught listening.

Second the teacher 2 develop CK (Content Knowledge) she able to taught learning material appropriate with the syllabus and involved knowledge of general facts, concepts, and theories its mean she able explained the material the concept and general facts the to the student in beginning taught.

Third teacher 2 develop PK (Pedagogical Knowledge) she able applies theory of classroom management in classroom, able to make effective lesson plan and syllabus, she able make assessment and evaluation learning before the start taught the teacher review the student about in the last week what the last week she taught, and teacher able communication with the student.

Fourth teacher 2 develop TPACK (Technology pedagogical content knowledge) she able to is able to design lesson plan involved technology, taught used technology that appropriate with learning material, and she manage the class by using technology. She taught with the audio and the material is missing lyric the student listen the song and the student wrote the missing lyric and then in the last class the teacher used program from Cambridge book for the review material in the program there question and answer automatic.

The result observed show in first meeting the teacher 1 dominant develop TPACK Framework with the component CK (Content knowledge) and TK (Technology Knowledge) and then teacher 2 develop instrument design TPACK framework in the listening classroom.

\section{CONCLUSION}

This study has revealed the results of exploring develop instrument design in listening classroom with TPACK in listening classroom. From the observation in SMA Budi Bakti and the check list with indicator guide there is different the teacher 1 and 2 with develop instrument design in listening classroom with TPACK Framework. The different teacher 1 dominant with CK ( content knowledge) and PK ( pedagogical knowledge) and able to is able to design lesson plan involved technology, taught used technology that appropriate with learning material, and she manage the class by using technology. This the conclusion of the research in SMA Budi Bakti about develop instrument design in listening classroom with TPACK framework.

\section{REFERENCES}

Arbain, A. (2017). Students narrative essay construction ability. JELE (Journal of English Language and Education), 3(1), 63-68. https://doi.org/https://doi.org/10.26486/jele.v3i1.255 
IJOTL TL, Vol. 5, No. 1, January 2020

p ISSN: 2502 2326; e ISSN: 2502 8278

Https://soloclcs.org; Email: ijolt1@gmail.com

Center of Language and Cultural Studies, Surakarta, Indonesia

Rustanto, Kristina; Nur, Dedi Rahman \& Mitriana, Rinda. 2020. Exploring the Use of TPACK

in Teaching Listening.

IJOTL TL (2020), 5(1): 45 50. DOI: 10.30957/ijot1 fl.v5i1.614.

Arbain, Arbain, Taufik, A., Ngoc, T. T. N., \& Nur, D. R. (2017). Basic English Drill. Yogyakarta: Andi Publisher.

Arbain, Arbain, Taufik, A., \& Nur, D. R. (2017). Daily English Phrases Book. Samarinda: UWGM Press.

Brown, H. Doughlas. (2000). Principles of Language Learning and Teaching, 4th Edition. Addison Wesley Longman, Inc.

Brown, D. H. (2007). First Language Acquisition, Principles of Language Learning and Teaching. Pearson ESL. Pgs, 24-51. Retrieved from http://cmmr.usc.edu/543/Brown_First_Language_Acquisition.PDF

Bugueño, W. M. R. (2013). Using TPACK to promote effective language teaching in an ESL / EFL classroom, 1-60.

Cohen, L., Manion, L., \& Morrison, K. (2013). Research Methods in. The Handbook of Psychology - Vol2 Methods 2 Specific methods.

Creswell, J. W. (2013). Research Design: Qualitative, Quantitative, and Mixed Methods Approaches. Research design Qualitative quantitative and mixed methods approaches.

Hasyuni. (2006). The Students' Preferred Activities for English Listening Classes (A Survey Conducted to the Second and Fourth Semester Students of English Department of FKIP.

HELGESEN, M. (2003). Listening in Practical Language Teaching. Edited by David Nunan. Mcgraw-hill.

Mishra, P., Koehler, M. J., \& Bragg, W. H. (2006). Technological Pedagogical Content Knowledge: A Framework for Teacher Knowledge The advent of digital technology has dramatically changed routines and practices in most arenas of human work. Advocates of technology in ed- ucation often envisage similar dra. Teachers College Record, 108(6), 1017-1054.

Morley, J. (2001). Aural Comprehension instruction: Principles and practices. In M. CelceMurcia, Teaching English as a second of foreign language (Third ed.). Boston: Heinle, Cengage Learning.

Naran, P., \& Köse, K. (2016). Technological Pedagogical Content Knowledge (Tpack) of English Language Instructors, (May), 12-19. Retrieved from

Pinnell, G. S., \& Jagger, A. M. (2003). Oral language: Speaking and listening in elementary classrooms. In J. Flood, D. Lapp, J. R. Squire, \& J. Jensen (Eds.), Hand-book of research on teaching the English language arts, 881-913.

Roblyer, M. D. (2006). Integrating educational technology into teaching. 4th ed. 